Anke Inselmann

\title{
Die Freude im Lukasevangelium
}

\author{
Ein Beitrag zur psychologischen Exegese
}

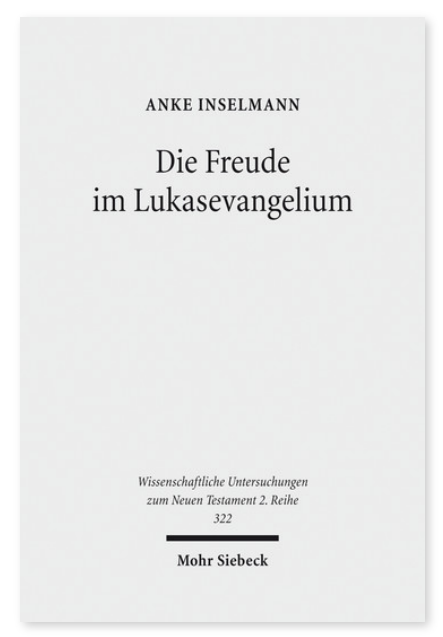

2012. XV, 491 Seiten. WUNT II 322

ISBN 978-3-16-152089-1

DOI 10.1628/978-3-16-152089-1

eBook PDF $114,00 €$

ISBN 978-3-16-150313-9

fadengeheftete Broschur 114,00€
Das Lukasevangelium verheißt eine »große Freude«. Dieser Affekt wird zum Leitmotiv wie in keinem anderen frühchristlichen Zeugnis. Viele intratextuelle Bezüge zeigen, dass der Verfasser ein reflektiertes Konzept verfolgt. Anke Inselmann untersucht, wie das Verständnis der Freude im Verlauf der Erzählung entfaltet und definiert wird. Auf der Grundlage einer historischkritischen und literaturwissenschaftlichen Analyse werden antike Affektpsychologie und moderne Emotionstheorien in die Exegese einbezogen. So wird deutlich, dass das Lukasevangelium mit verschiedenen Modellen zur Affektkontrolle anleiten will. Der Verfasser zielt dabei auf eine Freude, die beständig, kognitiv kontrolliert und mit unmittelbaren

Handlungskonsequenzen verbunden ist. Sie ist nicht dem philosophisch Weisen vorbehalten, sondern wird auch einfachen Menschen der christlichen Gemeinschaft zugeschrieben. Damit wirbt Lukas in seinem Umfeld für ein attraktives Christentum, das durch Freude charakterisiert ist.

Anke Inselmann Geboren 1974; Studium der ev. Theologie, Germanistik, Politikwissenschaften und Pädagogik in Stuttgart, Hamburg und Heidelberg; seit 2003 wissenschaftliche Mitarbeiterin am Institut für ev. Theologie mit Schwerpunkt biblische Theologie an der Universität Augsburg; 2008 Promotion; seit 2009 Akademische Rätin der Universität Augsburg.

Jetzt bestellen:

https://mohrsiebeck.com/buch/die-freude-im-lukasevangelium-9783161520891?no_cache=1 order@mohrsiebeck.com

Telefon: +49 (0)7071-923-17

Telefax: $+49(0) 7071-51104$ 